\title{
Pengaruh Perbandingan Terigu Dengan Tepung Kecambah Kacang Merah (Phaseolus vulgaris L.) Terhadap Karakteristik Kue Lumpur
}

\section{The Effect of Comparison of Wheat Flour with Red Bean Sprout Flour (Phaseolus vulgaris L.) on the Characteristics of Lumpur Cake}

\author{
Abiburrahim $^{1^{*}}$, Ni Wayan Wisaniyasa ${ }^{1^{*}}$, I Gusti Ayu Ekawati $^{1}$ \\ Program Studi Teknologi Pangan, Fakultas Teknologi Pertanian, Universitas Udayana \\ Kampus Bukit Jimbaran, Badung-Bali \\ *Penulis korespondensi: Ni Wayan Wisaniyasa, Email: wisaniyasa@unud.ac.id
}

\begin{abstract}
The purpose of this study was to determine the effect of wheat flour comparison with red bean sprout flour on the characteristics of lumpur cakes and to determine the ratio of wheat flour to red bean sprouts flour which can produce mud cakes with the best characteristics. This research used a Completely Randomized Design (CRD) with a comparison of flour and red bean sprouts as treatment. Treatment consisting of 6 levels $(100 \%: 0 \%, 80 \%: 20 \%, 60 \%: 40 \%, 40 \%: 60 \%$, 20\%: 80\%, and $0 \%: 100 \%$ ). The experimentation was repeated 3 times So that it is obtain 18 experimental units. Observed variables of moisture content, ash content, protein content, fat content, crude fiber content, color, aroma, taste, texture, and overall acceptance of lumpur cakes. The data obtained were then analyzed by variants and if there was any effect on the treatment, then continued with Duncan test. The results showed that the addition of red bean sprout affected moisture content, ash content, protein content, fat content, crude fiber content, color, aroma, taste, texture, and overall acceptance of lumpur cakes. The best characteristic of lumpur cake substitution was $60 \%$ wheat flour and $40 \%$ red bean sprouts flour that produced moisture content of $35,62 \%$, an ash content of $0,78 \%$, protein content of $11,09 \%$, a fat content of $36,67 \%$, crude fiber content of 16,47\%, regular color (normal), aroma (like), soft texture (like), taste (like), and overall acceptance (like).
\end{abstract}

Keywords: lumpur cake, wheat flour, red bean sprouts flour.

\section{PENDAHULUAN}

Kue lumpur adalah salah satu kue khas Indonesia yang menjadi camilan favorit kalangan tua dan muda karena citarasanya manis, legit, dan teksturnya yang lembut yang diolah dengan proses pemanggangan (Sundoko, 2006). Kue lumpur yang bercita rasa original dibuat dari campuran terigu, gula pasir, telur dan santan. Biasanya bagian atas diberi isi yang terdiri dari potongan kelapa muda dan kismis (Muaris, 2004). Kue lumpur biasanya dijadikan makanan pelengkap pada saat acara hajatan maupun perayaan hari raya. Kandungan gizi kue lumpur terdiri dari karbohidrat $44,1 \%$, lemak $11,1 \%$, protein $3,6 \%$, air $40,1 \%$ dan energi 291 kkal (Tihan, 2014).

Bahan utama dalam pembuatan kue lumpur adalah terigu. Sejak tahun 2018, Indonesia menjadi negara pengimpor gandum terbanyak didunia dengan jumlah 10.096.299 ton. Ini merupakan 6,1 $\%$ dari jumlah total impor dunia dan diperkirakan Indonesia akan membutuhkan sekitar 11,3 juta ton gandum dari pasar global pada periode 2019-2020 (USDA, 2019). Berdasarkan hal tersebut untuk mengurangi ketergantungan terhadap terigu maka perlu diupayakan penggunaan bahan pangan lokal 
seperti kacang-kacangan salah satunya kacang merah (Phaseolus vulgaris L.).

Kacang merah (Phaseolus vulgaris L.) merupakan komoditas kacang-kacangan yang sangat dikenal masyarakat. Menurut Badan Pusat Statistik (2020), pada tahun 2019, produksi kacang merah di Indonesia mencapai angka 61,517 ton. Kacang merah (Phaseolus vulgaris L.) memiliki kandungan protein cukup tinggi, yaitu antara 2127\% (Rukmana, 2009). Kacang merah kering merupakan sumber protein nabati, karbohidrat kompleks, serat, vitamin B, folasin, tiamin, kalsium, fosfor dan zat besi. Selain memiliki kandungan gizi yang tinggi, kacang merah juga memiliki kelemahan yaitu mengandung zat antigizi seperti antitripsin. Salah satu upaya untuk mengurangi kandungan antitripsin pada kacang merah bisa dilakukan dengan proses perkecambahan.

Menurut Torres et al., (2007), proses perkecambahan dapat menurunkan aktivitas antitripsin sebanyak $35 \%$ dan juga dapat memperbaiki kualitas nutrisi yang ada pada biji yang dikecambahkan. Proses perkecambahan terbukti dapat meningkatkan kadar serat pangan sehingga dapat dijadikan pangan fungsional (Astawan, 2009). Nilai dan mutu gizi kacang yang dikecambahkan menjadi lebih baik setelah dikecambahkan. Selama pengecambahan komponen antigizi (tripsin inhibitor, asam pitat, pentosan dan tannin) menurun dan setelah pengecambahan terbentuk komponen fitokimia glokosinolates, antioksidan alami yang berperan untuk kesehatan (Marto, 2010).
Proses perkecambahan kacang yang menghasilkan kecambah, yang kemudian ditepungkan memiliki nilai gizi yang lebih tinggi. Menurut Wisaniyasa \& Suter (2016), kadar protein tepung kecambah kacang merah sebesar 17,59 \%, sedangkan kadar protein tepung kacang merah hanya berkisar 13,96 \%. Hal ini dikarenakan pada saat proses perkecambahan terbentuk asam-asam amino baru yang tidak ada sebelumnya di kacang merah. Selain kadar proteinnya meningkat, tepung kecambah kacang merah ini juga tinggi serat pangan, perkecambahan mampu meningkatkan kadar serat pangan menjadi $34,29 \%$, dari yang sebelumnya hanya $32,23 \%$ tanpa melalui proses perkecambahan (Wisaniyasa dan Suter, 2016).

Penggunaan tepung kecambah kacang merah dalam pembuatan Kue Lumpur bertujuan untuk meningkatkan penggunaan bahan lokal dalam pembuatan suatu produk makanan sehingga akan mendukung mengurangi ketergantungan pada terigu, Untuk itu perlu dilakukan penelitian pembuatan kue lumpur dengan memvariasikan perbandingan terigu dengan tepung kecambah kacang merah dengan harapan produk pangan yang dihasilkan mempunyai gizi yang lebih tinggi.

\section{METODE PENELITIAN}

\section{Tempat dan Waktu Penelitian}

Penelitian ini dilaksanakan di Laboratorium Pengolahan Pangan dan Laboratorium Analisis Pangan, Fakultas Teknologi Pertanian, Universitas Udayana. Pelaksanaan penelitian ini dilakukan pada bulan Agustus sampai September 2020. 


\section{Bahan dan Alat}

Bahan utama yang digunakan dalam penelitian ini dibagi menjadi tiga bagian yaitu bahan utama, bahan tambahan dan bahan kimia. Bahan utama yang digunakan adalah terigu (segitiga biru) yang diperoleh dari pasar Jimbaran, kacang merah segar yang diperoleh dari pasar Jimbaran. Bahan pembantu yang digunakan adalah Gula (gulaku), telur, santan dan margarin (blueband) yang diperoleh dari Toko Nirmala Jimbaran. Bahan-bahan kimia yang digunakan untuk analisis kimia meliputi $\mathrm{H}_{2} \mathrm{SO}_{4}$ (Merck), NaOH PA (Merck), HCl (Merck), heksan (Merck), alkohol 96\% (Merck), Tablet kjeldahl (Merck), asam borat, $\mathrm{NaOH}$ teknis (Merck), aquades, dan indikator PP.

Alat - alat yang digunakan dalam melaksanakan penelitian ini antara lain waskom, timbangan analitik (Shimadzu), ayakan 60 mesh (Retsch), blender (miyako), mixer (Miyako), timbangan digital (EKS), kuas untuk ayakan, gelas ukur (Pyrex), kompor gas (Rinnai), sutil, sendok, gunting. Alat yang digunakan untuk analisis sifat fisik dan kimia adalah lumpang, kertas saring, kertas whatman 42, corong, eksikator, botol timbang, oven (Memmert), timbangan analitik (Shimadzu), aluminium foil, pinset, pipet tetes, pipet volume (Pyrex), kompor listrik, labu kjeldahl (Pyrex), destruktor, labu erlenmeyer (Pyrex), gelas beaker (Pyrex), gelas ukur (Pyrex), destilator, biuret (Pyrex), pompa karet, labu takar (Pyrex), water bath (thermology), kamera Hp (Realme), perangkat komputer dan lembar quisioner. Selain itu untuk evaluasi sensoris produk, alat yang digunakan adalah piring kertas.

\section{Rancangan Penelitian}

Rancangan percobaan yang digunakan dalam penelitian ini adalah Rancangan Acak Lengkap (RAL) dengan perlakuan perbandingan terigu dan tepung kecambah kacang merah yang terdiri dari 6 level, yaitu : $\mathrm{P} 0=100 \%$ (terigu) : $0 \%$ (tepung kecambah kacang merah); P1 $=80 \%$ (terigu) : 20\% (tepung kecambah kacang merah); P2 $=60 \%$ (terigu) : 40\% (tepung kecambah kacang merah); $\mathrm{P} 3=40 \%$ (terigu) : 60\% (tepung kecambah kacang merah); $\mathrm{P} 4=20 \%$ (terigu) : $80 \%$ (tepung kecambah kacang merah); P5 $=0 \%$ (terigu) : 100\% (tepung kecambah kacang merah). Masing-masing perlakuan diulang sebanyak 3 kali sehingga diperoleh sebanyak 18 unit percobaan. Data yang diperoleh akan dianalisis menggunakan sidik ragam dan apabila terdapat pengaruh dilanjutkan dengan Duncan's Multiple Range Test.

\section{Pelaksanaan Penelitian}

Tahap pelaksanaan penelitian meliputi tiga proses yaitu proses perkecambahan, pembuatan tepung kecambah kacang merah dan proses pembuatan kue lumpur.

\section{Proses Perkecambahan}

Kacang merah segar disortasi untuk memisahkan kotoran, lalu dicuci pada air mengalir, kemudian dikecambahkan dalam wadah keranjang plastik beralaskan dan ditutup daun pisang. Dikecambahkan selama 48 jam pada suhu kamar dan tanpa cahaya. Jumlah kacang merah masing masing perlakuan adalah $100 \mathrm{~g}$ dengan ketebalan 1 cm pada suhu kamar. Setiap perlakuan diperciki air secara merata sebanyak $10 \mathrm{ml}$ setiap 12 jam. 


\section{Proses pembuatan tepung kecambah kacang merah}

Tahapan selanjutnya setelah perkecambahan 48 jam, kecambah kacang merah dicuci, ditiriskan, lalu dipotong-potong. Kecambah kacang merah yang telah dipotong-potong diletakkan di atas loyang kemudian dioven pada suhu $50^{\circ} \mathrm{C}$ selama 26 jam. Setelah kering kecambah kacang merah diblender dan diayak dengan ayakan 60 mesh. Diagram alir pembuatan tepung kecambah kacang merah dapat dilihat pada Gambar 2.

\section{Proses pembuatan kue lumpur}

Proses pembuatan kue lumpur meliputi persiapan bahan, yaitu semua bahan (terigu, tepung kecambah kacang merah, telur, santan, margarin, dan gula pasir) disiapkan dan ditimbang sesuai formula yang sudah ditentukan. Telur $80 \mathrm{~g}$ dan gula $60 \mathrm{~g}$ dimixer sampai rata dan ditambahkan terigu dan tepung kecambah kacang merah sesuai perlakuan sambil dimixer selama 1 menit. Ditambahkan margarin cair $50 \mathrm{~g}$ ke dalam adonan dan dimixer kembali hingga rata. Ditambahkan santan $150 \mathrm{ml}$ sedikit demi sedikit sambil dimixer sampai rata. Setelah adonan jadi, dilakukan penuangan adonan pada cetakan kue lumpur yang sudah dipanaskan dan diolesi margarin. Adonan yang sudah dicetak selanjutnya dipanggang pada suhu $110^{\circ} \mathrm{C}$ selama 15 menit. Setelah matang kue lumpur dilepaskan dari cetakannya dan didinginkan pada suhu ruang. Kue lumpur siap dianalisis. Formula pembuatan kue lumpur dari tepung kecambah kacang merah dapat dilihat pada Tabel 1.

Tabel 1.Formulasi bahan baku pembuatan kue lumpur

\begin{tabular}{lllllll}
\hline \multirow{2}{*}{ Komposisi } & \multicolumn{7}{c}{ Perlakuan } \\
\cline { 2 - 6 } & P0 & P1 & P2 & P3 & P4 & P5 \\
\hline Terigu (g & 100 & 80 & 60 & 40 & 20 & 0 \\
Tepung kecambah & 0 & 20 & 40 & 60 & 80 & 100 \\
kacang merah (g) & & & & & & \\
Telur (\%) & 80 & 80 & 80 & 80 & 80 & 80 \\
Gula pasir (\%) & 60 & 60 & 60 & 60 & 60 & 60 \\
Margarin (\%) & 50 & 50 & 50 & 50 & 50 & 50 \\
Santan (\%) & 150 & 150 & 150 & 150 & 150 & 150 \\
\hline
\end{tabular}

Sumber : Kusniati (2009) yang telah dimodifikasi

\section{Variabel yang diamati}

Variabel yang diamati pada penelitian ini meliputi analisis kadar air dengan metode pengeringan (Sudarmadji et al., 1997), kadar abu metode pengabuan (Sudarmadji et al., 1997), kadar protein metode Kjeldahl (Sudarmadji et al., 1997), kadar lemak dengan metode soxhlet (Sudarmadji et al., 1997), kadar serat kasar yang dilakukan dengan metode hidrolisis asam basah (Sudarmadji et al., 1997), serta sifat sensoris yang meliputi warna, aroma, rasa, tekstur dan penilaian keseluruhan menggunakan uji hedonik dan uji skoring untuk tekstur dan warna (Soekarto, 1985).

\section{HASIL DAN PEMBAHASAN}

Hasil penelitian terhadap kadar air, kadar abu dan kadar protein kue lumpur dengan perbandingan terigu dengan tepung kecambah kacang merah dapat dilihat pada Tabel 2. Nilai 
rata-rata kadar lemak dan serat kasar pada kue

lumpur pada Tabel 3.

Tabel 2. Nilai rata-rata hasil analisis kadar air, kadar abu, kadar protein kue lumpur

\begin{tabular}{clll}
\hline $\begin{array}{c}\text { Perlakuan } \\
\text { (Terigu : TKKM) }\end{array}$ & Kadar air & Kadar abu & Kadar protein \\
\hline P0 $(100 \%: 0 \%)$ & $31,78 \pm 0,61 \mathrm{~d}$ & $0,56 \pm 0,05 \mathrm{~d}$ & $9,07 \pm 0,33 \mathrm{~d}$ \\
P1 $(80 \%: 20 \%)$ & $34,62 \pm 0,78 \mathrm{c}$ & $0,76 \pm 0,01 \mathrm{~cd}$ & $10,75 \pm 0,28 \mathrm{c}$ \\
P2 60\%:40\%) & $35,62 \pm 0,21 \mathrm{bc}$ & $0,78 \pm 0,06 \mathrm{~cd}$ & $11,09 \pm 0,28 \mathrm{bc}$ \\
P3 40\%:60\%) & $37,43 \pm 0,85 \mathrm{ab}$ & $1,10 \pm 0,10 \mathrm{bc}$ & $11,65 \pm 0,34 \mathrm{~b}$ \\
P4 20\%:80\%) & $38,17 \pm 0,29 \mathrm{a}$ & $1,27 \pm 0,13 \mathrm{~b}$ & $12,55 \pm 0,39 \mathrm{a}$ \\
P5 0\%:100\%) & $39,33 \pm 0,08 \mathrm{a}$ & $1,68 \pm 0,51 \mathrm{a}$ & $13,01 \pm 0,39 \mathrm{a}$ \\
\hline
\end{tabular}

Keterangan : Nilai rata - rata yang diikuti oleh huruf yang berbeda menunjukkan perlakuan berbeda nyata $(\mathrm{P}<0,05)$

Tabel 3. Nilai rata-rata hasil analisis kadar lemak dan kadar serat kasar kue lumpur

\begin{tabular}{ccc}
\hline $\begin{array}{c}\text { Perlakuan } \\
\text { (Terigu : TKKM) }\end{array}$ & $\begin{array}{c}\text { Kadar lemak } \\
(\mathbf{\%})\end{array}$ & $\begin{array}{c}\text { Kadar serat } \\
\mathbf{( \% )}\end{array}$ \\
\hline P0 $(100 \%: 0 \%)$ & $39,12+0,54 \mathrm{a}$ & $9,27 \pm 0,87 \mathrm{e}$ \\
P1 $(80 \%: 20 \%)$ & $37,43+1,03 \mathrm{~b}$ & $15,23 \pm 0,26 \mathrm{~d}$ \\
P2 60\%:40\%) & $36,67+0,46 \mathrm{~b}$ & $16,47 \pm 0,50 \mathrm{~cd}$ \\
P3 40\%:60\%) & $34,29+1,05 \mathrm{c}$ & $19,61 \pm 3,74 \mathrm{bc}$ \\
P4 20\%:80\%) & $33,83+0,76 \mathrm{~cd}$ & $22,74 \pm 2,98 \mathrm{ab}$ \\
P5 0\%:100\%) & $32,62+0,24 \mathrm{~d}$ & $26,40 \pm 1,30 \mathrm{a}$ \\
\hline
\end{tabular}

Keterangan : Nilai rata - rata yang diikuti oleh huruf yang berbeda menunjukkan perlakuan berbeda nyata $(\mathrm{P}<0,05)$

\section{Kadar air}

Hasil sidik ragam menunjukkan bahwa perbandingan terigu dan tepung kecambah kacang merah berpengaruh nyata $(\mathrm{P}<0,05)$ terhadap kadar air kue lumpur yang dihasilkan. Tabel 2 menunjukkan kadar air kue lumpur berkisar antara 31,78\%-39,33\%. Kadar air tertinggi dihasilkan pada perlakuan P5 sebesar 39.33\% tidak berbeda nyata $(\mathrm{P}<0,05)$ dengan perlakuan $\mathrm{P} 4$ dan $\mathrm{P} 3$ sedangkan kadar air terendah dihasilkan pada perlakuan $\mathrm{P} 0$ sebesar 31,78\%.

Tabel 2 menunjukkan terjadi peningkatan kadar air kue lumpur seiring dengan peningkatan penggunaan tepung kecambah kacang merah. Semakintinggi penambahan tepung kecambah kacang merah maka kadar air kue lumpur yang dihasilkan semakin meningkat. Hal ini disebabkan karena tepung kecambah kacang merah yang digunakan memiliki kadar air 6,38\%, lebih besar dibandingkan dengan terigu yang memiliki kadar air sebesar 6,07\% (Dewantari et al.,2016).

\section{Kadar abu}

Hasil sidik ragam menunjukkan bahwa perbandingan terigu dan tepung kecambah kacang merah berpengaruh nyata $(\mathrm{P}<0,05)$ terhadap kadar abukue lumpur yang dihasilkan. Tabel 2 menunjukkan kadar abukue lumpur berkisar antara 0,56\% - 1,68\%. Kadar abu tertinggi dihasilkan pada perlakuan P5 sebesar 1,68\% sedangkan kadar abu terendah dihasilkan pada perlakuan P0 sebesar $0,56 \%$. 
Tabel 2, menunjukkan terjadi peningkatan kadar abu kue lumpur seiring dengan peningkatan penggunaan tepung kecambah kacang merah. Semakin tinggi penambahan tepung kecambah kacang merah maka kadar abu kue lumpur yang dihasilkan semakin meningkat. Hal ini disebabkan karena tepung kecambah kacang merah yang digunakan memiliki kadar abu sebesar 4,28\%, lebih besar dibandingkan dengan terigu yang memiliki kadar abu sebesar 0,59\% (Dewantari, et al., 2016). Oleh karena itu, semakin meningkat penggunaan tepung kecambah kacang merah menyebabkan meningkatnya kadar abu kue lumpur.

\section{Kadar protein}

Hasil sidik ragam menunjukkan bahwa perbandingan terigu dan tepung kecambah kacang merah berpengaruh nyata $(\mathrm{P}<0,05)$ terhadap kadar protein kue lumpur yang dihasilkan. Tabel 2 menunjukkan kadar protein lumpur berkisar antara $9,07 \%-13,01 \%$. Kadar protein tertinggi dihasilkan pada perlakuan P5 sebesar 13,01\% tidak berbeda nyata $(\mathrm{P}<0,05)$ dengan perlakuan $\mathrm{P} 4$ sedangkan Kadar protein terendah dihasilkan pada perlakuan P0 sebesar 9,07\%.

Kadar protein kue lumpur meningkat seiring dengan peningkatan penggunaan tepung kecambah kacang merah. Hal ini dikarenakan kandungan protein tepung kecambah kacang merah lebih tinggi dibandingkan dengan terigu. Kandungan protein tepung kecambah kacang merah lebih tinggi yaitu sebesar 17,01\% dibandingkan terigu yang hanya memiliki kandungan protein sebesar 8,63\% (Dewantari, et al., 2016)

Terjadinya perbedaan kadarproteinkue lumpur yang dihasilkan dalam hal ini dipengaruhi oleh jenis dan rasio tepung. (Tinambunan et al.,2014 dalam Sundari,2015) menyatakan bahwa faktor yang memengaruhi kadar protein yaitu jenis tepung, rasio tepung.

\section{Kadar lemak}

Hasil sidik ragam menunjukkan bahwa perbandingan terigu dan tepung kecambah kacang merah berpengaruh nyata $(\mathrm{P}<0,05)$ terhadap kadar lemak kue lumpur yang dihasilkan. Tabel 3 menunjukkan kadar lemak lumpur berkisar antara $32,62 \%-39,12 \%$. Kadar lemak tertinggi dihasilkan pada perlakuan P0 sebesar 39,12\% sedangkan Kadar lemak terendah dihasilkan pada perlakuan P5 sebesar $32,62 \%$.

Semakin meningkat penambahan tepung kecambah kacang merah maka kadar lemak semakin menurun. Hal ini disebabkan karena kandungan lemak tepung kecambah kacang merah lebih rendah dibandingkan dengan terigu, kandungan lemak tepung kecambah kacang merah sebesar $8,12 \%$ sedangkan terigu memiliki kandungan lemak sebesar 8,96\% (Dewantari,et al., 2016).

\section{Kadar serat}

Hasil sidik ragam menunjukkan bahwa perbandingan terigu dan tepung kecambah kacang merah berpengaruh nyata $(\mathrm{P}<0,05)$ terhadap kadar serat kasar kue lumpur yang dihasilkan. Tabel 3 menunjukkan kadar serat kue lumpur berkisar antara $9,27 \%$ - 26,40\%. Kadar serat kasar tertinggi dihasilkan pada perlakuan P5 sebesar 26,40\% sedangkankadar serat kasar terendah dihasilkan pada perlakuan P0 sebesar 9,27\%.

Tabel 3 menunjukkan terjadi peningkatan kadar serat kue lumpur seiring dengan peningkatan penggunaan tepungkecambah kacang merah sebagai bahan pengganti terigu. Semakin tinggi penggunaan tepung kecambah kacang merah maka 
semakin tinggi kandungan serat kasar kue lumpur yang dihasilkan. Hal ini disebabkan karena peningkatan kadar serat kasar ini seiring dengan peningkatan penggunaan tepung kecambah kacang merah, karena tepung kecambah kacang merah memiliki kandungan serat kasar yang jauh lebih tinggi yaitu $11,91 \%$ dibandingkan dengan terigu yang hanya memiliki kadar serat kasar 5,32\%.

Tingginya serat kasar pada tepung kecambah kacang merah tentunya dapat menjadi nilai lebih pada kue lumpur yang dihasilkan. Kadar serat kasar yang tinggi pada tepung kecambah kacang merah diakibatkan karena terjadinya proses perkecambahan sebelum dibuat menjadi tepung. Menurut Indrastati dan Anjani (2016) tepung kacang merah mengandung serat kasar sebesar 5,5$6,1 \%$. Sedangkan pada tepung kacang merah yang sudah dikecambahkan memiliki kadar serat kasar sebesar 10,28\%. Proses perkecambahan dapat meningkatkan kadar serat pada kacang merah dikarenakan pada proses perkecambahan berlangsung mobilisasi cadangan makanan dari jaringan penyimpanan atau keping biji ke bagian vegetatif, yaitu pada sumbu pertumbuhan embrio atau lembaga sehingga terjadi peningkatan massa pada biji kacang merah selama perkecambahan. Selama terjadi proses perkecambahan ini, cadangan makanan pada biji kacang merah dapat dimanfaatkan oleh manusia untuk dikonsumsi.

\section{Sifat Sensoris}

Sifat sensoris kue lumpur dilakukan dengan uji hedonik dan skoring.Uji hedonik dilakukan terhadap warna, aroma, tekstur, rasa, dan penerimaan keseluruhan.Uji skoring dilakukan terhadap warna dan tekstur. Nilai rata-rata uji hedonik terhadap warna, aroma, tekstur, rasa, dan penerimaan keseluruhan kue lumpur dapat dilihat pada Tabel 4.Nilai rata-rata uji skoring terhadap warna dan tekstur dapat dilihat pada Tabel 5.

Tabel 4. Nilai rata-rata uji hedonik warna, aroma, tekstur, rasa, dan penerimaan keseluruhan kue lumpur.

\begin{tabular}{|c|c|c|c|c|c|}
\hline \multirow{2}{*}{$\begin{array}{c}\text { Perlakuan } \\
\text { (Terigu : TKKM) }\end{array}$} & \multicolumn{5}{|c|}{ Nilai Rata-Rata Uji Hedonik } \\
\hline & Warna & Aroma & Tekstur & Rasa & $\begin{array}{c}\text { Penerimaan } \\
\text { Keseluruhan }\end{array}$ \\
\hline P0 (100\%:0\%) & $4,3 \mathrm{a}$ & $4,5 \mathrm{a}$ & $4,5 \mathrm{a}$ & $4,8 \mathrm{a}$ & $4,6 \mathrm{a}$ \\
\hline P1 (80\%:20\%) & $4,35 \mathrm{a}$ & $4,35 \mathrm{ab}$ & $4,55 \mathrm{a}$ & $4,4 \mathrm{ab}$ & $4,45 \mathrm{ab}$ \\
\hline P2 (60\%:40\%) & $3,8 \mathrm{ab}$ & $4,1 \mathrm{ab}$ & $4 \mathrm{a}$ & $4,1 \mathrm{~b}$ & $4,3 a b$ \\
\hline P3 (40\%:60\%) & $3,6 \mathrm{~b}$ & $3,75 \mathrm{bc}$ & $3,95 \mathrm{a}$ & $3,95 \mathrm{~b}$ & $4 \mathrm{~b}$ \\
\hline P4 (20\%:80\%) & $2,55 \mathrm{c}$ & $3,3 \mathrm{c}$ & $2,75 \mathrm{~b}$ & $2,75 \mathrm{c}$ & $2,45 \mathrm{c}$ \\
\hline P5 (0\%:100\%) & $2,15 \mathrm{c}$ & $2,4 \mathrm{~d}$ & $2,3 \mathrm{~b}$ & $2,1 \mathrm{c}$ & $2,1 \mathrm{c}$ \\
\hline
\end{tabular}

Keterangan : Nilai rata - rata yang diikuti oleh huruf yang berbeda menunjukkan perlakuan berbeda nyata $(\mathrm{P}<0,05)$

\section{Warna}

Hasil sidik ragam berdasarkan uji hedonik menunjukkan bahwa perbandingan terigu dan tepung kecambah kacang merah berpengaruh nyata $(\mathrm{P}<0,05)$ terhadap warna kue lumpur. Tabel 4 menunjukkan nilai rata-rata uji hedonik kue lumpur berkisar antara 2,15 (agak tidak suka) sampai dengan 4,3 (suka). Nilai rata-rata kesukaan panelis terhadap warna tertinggi pada perlakuan $\mathrm{P} 0$ dengan kriteria suka dan tidak berbeda nyata $(\mathrm{P}<0,05)$ 
dengan perlakuan $\mathrm{P} 1$ sedangkan nilai terendah diperoleh perlakuan P5 yaitu dengan kriteria agak tidak suka.

Hasil sidik ragam berdasarkan uji skoring menunjukkan bahwa perbandingan terigu dan tepung kecambah kacang merah berpengaruh nyata $(\mathrm{P}<0,05)$ terhadap warna kue lumpur. Tabel 5 menunjukan nilai rata-rata uji skoring kue lumpur berkisar antara 1 (tidak coklat) sampai dengan 4,55(sangat coklat). Nilai rata-rata skor tertinggi terhadap warna kue lumpur diperoleh perlakuan P5 yaitu 4,55 dengan kriteria cokelat, sedangkan nilai rata-rata skor terendah terdapat pada perlakuan P0 dengan kriteria tidak coklat dan tidak berbeda nyata $(\mathrm{P}<0,05)$ dengan perlakuan $\mathrm{P} 1$. Panelis menyatakan bahwa semakin tinggi penambahan tepung kecambah kacang merah maka warna pada kue lumpur menjadi lebih coklat. Hal ini disebabkan karena adanya pigmen antosianin yang dikandung oleh tepung kecambah kacang merah, sehingga memengaruhi warna dari kue lumpur yang dihasilkan.

Tabel 5. Nilai rata-rata uji skoring tekstur dan warna

\begin{tabular}{ccc}
\hline \multirow{2}{*}{$\begin{array}{c}\text { Perlakuan } \\
\text { (Terigu:TKKM) }\end{array}$} & \multicolumn{2}{c}{ Nilai Rata-Rata Uji Skoring } \\
\cline { 2 - 3 } & Warna & Tekstur \\
\hline P0 $(100 \%: 0 \%)$ & $1 \pm 0,00 \mathrm{a}$ & $4,6 \pm 0,88 \mathrm{a}$ \\
P1 $(80 \%: 20 \%)$ & $2,35 \pm 0,59 \mathrm{a}$ & $4,45 \pm 0,75 \mathrm{a}$ \\
P2 (60\%:40\%) & $3,1 \pm 0,85 \mathrm{~b}$ & $4,2 \pm 0,69 \mathrm{ab}$ \\
P3 (40\%:60\%) & $2,95 \pm 0,76 \mathrm{~b}$ & $3,8 \pm 0,89 \mathrm{~b}$ \\
P4 (20\%:80\%) & $4,15 \pm 0,67 \mathrm{c}$ & $2,55 \pm 0,88 \mathrm{c}$ \\
P5 (0\%:100\%) & $4,55 \pm 0,69 \mathrm{~d}$ & $1,8 \pm 0,89 \mathrm{~d}$ \\
\hline
\end{tabular}

Keterangan : Nilai rata - rata yang diikuti oleh huruf yang berbeda menunjukkan perlakuan berbeda nyata $(\mathrm{P}<0,05)$

\section{Aroma}

Hasil sidik ragam berdasarkan uji hedonik menunjukkan bahwa perbandingan terigu dan tepung kecambah kacang merah berpengaruh nyata $(\mathrm{P}<0,05)$ terhadap aroma kue lumpur. Tabel 4 menunjukkan nilai rata-rata uji hedonik kue lumpur berkisar antara 2,4 (biasa) sampai dengan 4,5 (suka). Nilai rata-rata kesukaan panelis terhadap aroma tertinggi pada perlakuan P0 dengan kriteria suka dan tidak berbeda nyata $(\mathrm{P}<0,05)$ dengan perlakuan $\mathrm{P} 1$ sedangkan nilai terendah diperoleh perlakuan P5 dengan kriteria agak tidak suka. Aroma juga menjadi faktor penentu daya terima panelis karena suatu produk meskipun memiliki warna atau ciri visual yang baik namun aromanya tidak menarik akan mempengaruhi ketertarikan panelis (Khasanah, 2003).

\section{Tekstur}

Hasil sidik ragam berdasarkan uji hedonik menunjukkan bahwa perbandingan terigu dan tepung kecambah kacang merah berpengaruh nyata $(\mathrm{P}<0,05)$ terhadap nilai sensoris kesukaan tekstur kue lumpur. Tabel 4 menunjukkan nilai rata-rata uji hedonik berkisar antara 2,3 (agak tidak suka) sampai dengan 4,5 (suka). Nilai rata-rata kesukaan panelis terhadap tekstur tertinggi pada perlakuan P0 dengan kriteria suka dan tidak berbeda nyata $(\mathrm{P}<0,05)$ dengan perlakuan $\mathrm{P} 1$ sedangkan nilai terendah diperoleh perlakuan P5 dengan kriteria agak tidak suka. 
Hasil sidik ragam berdasarkan uji skoring menunjukkan bahwa perbandingan terigu dan tepung kecambah kacang merah berpengaruh nyata $(\mathrm{P}<0,05)$ terhadap tekstur kue lumpur. Tabel 5 menunjukan nilai rata-rata uji skoring kue lumpur berkisar antara 1,8 (agak tidak lembut) sampai dengan 4,6 (sangat lembut). Nilai rata-rata skor tertinggi terhadap tekstur kue lumpur diperoleh pada perlakuan P0 dengan kriteria sangat lembut, nilai rata-rata skor terendah terdapat pada perlakuan P5 dengan kriteria agak lembut.

Semakin tinggi penggunaan tepung kecambah kacang merah maka nilai kelembutan kue lumpur semakin menurun. Hal ini disebabkan karena peningkatan penggunaan tepung kecambah kacang merahakan mengurangi jumlah gluten pada adonan tepung.

\section{Rasa}

Hasil sidik ragam berdasarkan uji hedonik menunjukkan bahwa perbandingan terigu dan tepung kecambah kacang merah berpengaruh nyata $(\mathrm{P}<0,05)$ terhadap rasa kue lumpur. Tabel 4 menunjukkan nilai rata-rata uji hedonik kue lumpur berkisar antara 2,1 (agak tidak suka) sampai dengan 4,8 (sangat suka). Nilai rata-rata kesukaan panelis terhadap rasa tertinggi pada perlakuan P0 dengan kriteria sangat suka dan tidak berbeda nyata $(\mathrm{P}<0,05)$ dengan perlakuan $\mathrm{P} 1$ sedangkan nilai terendah diperoleh perlakuan P5 yaitu dengan kriteria agak tidak suka.

Kue lumpur dengan perlakuan P0 sampai dengan P2 berada dalam kategori tingkat kesukaan yang sama, yaitu suka, sehingga dapat dikatakan bahwa panelis dapat menerima kue lumpur dengan penggunaan tepung kecambah kacang merah sampai dengan 40\%. Panelis menyatakan bahwa semakin tinggi penambahan tepung kecambah kacang merah maka rasa pada kue lumpur akan kurang disukai, hal ini dikarenakan semakin banyak penambahan tepung kecambah kacang merah maka rasa kue lumpur semakin langu.

\section{Penerimaan Keseluruhan}

Hasil sidik ragam menunjukkan bahwa perbandingan terigu dan tepung kecambah kacang merah berpengaruh nyata $(\mathrm{P}<0,05)$ terhadap penerimaan keseluruhan kue lumpur dengan uji hedonik. Tabel 4 menunjukkan nilai rata-rata uji hedonik kue lumpur berkisar antara 2,1 (agak tidak suka) sampai dengan 4,6 (suka). Nilai rata-rata kesukaan panelis terhadap penerimaan keseluruhan tertinggi pada perlakuan P0 dengan kriteria suka sedangkan nilai terendah diperoleh pada perlakuan P5 yaitu dengan kriteria agak tidak suka dan tidak berbeda nyata $(\mathrm{P}<0,05)$ dengan perlakuan $\mathrm{P} 4$. Penerimaan keseluruhan dipengaruhi oleh beberapa faktor seperti warna, aroma, tekstur dan rasa kue lumpur.

\section{KESIMPULAN DAN SARAN}

\section{Kesimpulan}

Perbandingan terigu dan tepung kecambah kacang merah berpengaruh terhadap kadar air, kadar abu, kadar protein, kadar lemak, kadar serat kasar, warna, aroma, tekstur, rasa dan penerimaan keseluruhan. Perbandingan terigu $60 \%$ dan tepung kecambah kacang merah 40\% menghasilkan kue lumpur dengan karakteristik terbaik dengan kadar air 35,62\%, kadar abu 0,78, kadar protein 11,09\%, kadar lemak 56,95\%, kadar serat kasar 16,47\%, warna agak tidak coklat dan suka, aroma suka, tekstur lembut dan suka, rasa suka, dan penerimaan keseluruhan suka 


\section{Saran}

Berdasarkan hasil penelitian ini disarankan untuk menggunakan perbandingan terigu $60 \%$ dan tepung kecambah kacang merah $40 \%$ dalam pembuatan kue lumpur, serta dilakukan penelitian lebih lanjut mengenai penambahan bahan lain agar tekstur lebih lembut dan rasa semakin disukai sehingga dapat meningkatkan penerimaan keseluruhan dan dapat menambah daya tarik terhadap kue lumpur.

\section{DAFTAR PUSTAKA}

Agustin,V., I.M. Sugitha, dan P. A. Wipradnyadewi.2017. Pengaruh perbandingan terigu dengan puree labu kuning (Cucurbita Moschata ex. Poir) terhadap karakteristik kue lumpur. Jurnal ITEPA 6(2):11-20.

Anggrek,T.D. 2009. 500 Resep lezat selera nusantara. Pustaka Anggrek, Yogyakarta.

Anonimous. 1992. Standar Nasional Indonesia (SNI) 01-2974-1992 Syarat mutu tepung terigu.

Astawan, M. (2009).Sehat dengan Hidangan Kacang dan Biji-bijian. Penebar Swada, Bogor

Dewantari, I.G.A., N.W. Wisaniyasa, dan I.K. Suter. 2016. Pengaruh substitusi terigu dengan tepung kecambah kacang merah (Phaseolus vulgaris L.) terhadap Karakteristik cookies. Skripsi. Jurusan Teknologi Pangan, Fakultas Teknologi Pertanian, Universitas Udayana.

Khasanah, U. 2003. Formulasi karakterisasi fisikokimia dan organoleptic produk makanan sarapan ubi jalar (Sweet potato flakes). Skripsi.Tidak dipublikasikan. Institute Pertanian Bogor, Bogor

Kusmiati, A. 2009.50 Resep Kue Paling Diminati Koleksi Dapur Mara.PT. Gramedia Pustaka Utama. Jakarta.

Marta,S.,O. Erza. 2010. Analisis efisiensi industri gula di indonesia dengan metode data envelopment analysis (Dea) Tahun 2001 - 2010. Jurnal Media Ekonomi. 18(3):1-19

Muaris, H. 2004. Seri Makanan Favorit : kue lumpur. www.bukabuku.com. Diakses tanggal 13 Januari 2020.

Rukmana, R. 2009. Budidaya Buncis. Penerbit Kanisius. Jakarta
Santoso, 1999. Kesehatan dan Gizi. Jakarta: PT.Rineka Cipta

Soekarto, S.T. 1985. Penilaian Organoleptik untuk Industri Pangan dan Pertanian. Bharata Karya Aksara. Jakarta.

Soenardi, T. 2010. Pustaka Kuliner Lengkap 1500 Resep Masakan Sehat untuk Bayi Hingga Manula.PT. Gramedia Pustaka Utama. Jakarta.

Sudarmadji,S., B. Haryono dan Suhardi.1997. Analisa Bahan Makanan dan Pertanian. Liberty, Jakarta.

Sunarsi, S., M. Sugeng., S. Wahyuni, dan W. Ratnaningsih. 2011. Memanfaatkan singkong menjadi tepung mocaf untuk pemberdayaan masyarakat sumberejo. Pangan dan Agroindustri, 1(1):306-316.

Sundari, D. 2015. Pengaruh proses pemasakan terhadap komposisi zat gizi bahan pangan sumber protein. Jakarta Pusat:Media Litbangkes, 25(4):235-242.

Sundoko, L. S. 2006. Seri Kue Basah Favorit : Kue Lumpur Aneka Rasa. PT Gramedia Pustaka Utama, Jakarta.

Suryatna, B. S. 2015. Peningkatan kelembutan tekstur roti melalui fortifikasi rumput laut (Euchema cottoni). Jurnal PKK, Fakultas Teknik, UNNES. 2(2):18-24

Syarief, R. dan H. Halid. 1990. Buku monograf teknologi penyimpanan pangan. laboratorium rekayasa pangan dan gizi.institut pertanian bogor. Bogor.

Tihan, E. S. T. L. 2014. Kandungan gizi beberapa jenis kue basah. Available from: https://www.scribd.com/doc/133370608/Kandun gan-Gizi-Beberapa-Jenis-Kue-Basah. Diakses 27 November 2019.

Tinambunan, N., H. Rusmarilin., dan M. Nurminah. 2014. Pengaruh rasio tepung talas, pati talas dan terigu dengan penambahan $\mathrm{cmc}$ terhadap sifat kimia dan organoleptik mi instan. Jurnal Rekayasa Pangan dan Pertanian, 2(3):30-39.

Torres, A., Frias, J., Granito, M. dan Vidal, C. 2006. Fermented pigeon pie (cajanus cajan) ingredient in pasta product. Journal of Agricultural Food Chemistry. 101(18):202-211.

Wahyudi. 2003. Memproduksi Roti. Direktorat Pendidikan Menengah Kejuruan Direktorat Jenderal Pendidikan

Wisaniyasa, N.W. dan I. K. Suter. 2016. Kajian sifat fungsional dan kimia tepung kecambah kacang merah (Phaseolus vulgaris L.). Media Ilmiah Teknologi Pangan 3(1):26-34. 